REPORTS OF MORPHOLOGY
$\begin{gathered}\text { Official Journal of the Scientific Society of Anatomists, } \\ \text { Histologists, Embryologists and Topographic Anatomists } \\ \text { of Ukraine } \\ \text { journal homepage: https://morphology-journal.com }\end{gathered}$

\title{
Structural changes of the intestinal epithelial barrier of the duodenum of rats in burn injury of skin under experimental streptozotocin-induced diabetes mellitus
}

Tymoshenko I.O.

O.O. Bogomolets National Medical University, Kyiv, Ukraine

\section{ARTICLEINFO}

Received: 21 February, 2019

Accepted: 20 March, 2019

UDC: $616.342: 616-001.17: 616.379-$ 008.64:599.323.4:612.08

\section{CORRESPONDING AUTHOR}

e-mail: iryna.tymoshenko@i.ua Tymoshenko I.O.
The aim of the study was to study the structural changes of the intestinal epithelial barrier in the duodenum in burn injury of skin in rat under experimental streptozotocin-induced diabetes mellitus. The study was carried out on laboratory white adult rats-males weighing 180-210 g. The control group consisted of 21 animals without somatic pathology, the first experimental group was 21 rats with burn skin injury, the second experimental group was 21 rats with burn skin and experimental streptozotocin-induced diabetes mellitus. The experimental diabetes model was reproduced by administering streptozotocin to the rats intraperitoneally at a single dose of $50 \mathrm{mg} / \mathrm{kg}$. Thermal burn skin damage in rats corresponded to II - $A-B$ degrees of dermal surface burn (according to the old classification III - A degree) with a total area of 21-23\% of the body surface with the development of burn shock. Duodenum was selected for morphological studies, fragments of which were processed by conventional methods of light and electron microscopy. The main criteria for assessing damage to the duodenal mucosa enterocytes were the results of a study comparing histological and ultrastructural data in dynamics at 7, 14, and 21 days after skin burns. The results of the studies showed that the base of damage to the intestinal epithelial barrier of the duodenum are deep destructive changes, which after 21 days (in the stage of septicotoxemia), as a rule, are not reverse and develop on the background of significant intoxication of the body. There was a decrease in the number of tight junctions in the intestinal epithelial barrier of the duodenum of rats of the first and second experimental groups and a loss of ordering (acquisition of some chaotic nature) of their localization as the time after burn injury increased. For the most part, the intestinal epithelial barrier loses the integrity of the cellular component with partial preservation of the basement membrane (the first occurs both due to necrosis of the enterocytes with a brush border and due to complete destruction of goblet cells). In all cases, defects exist in the intestinal epithelial barrier, which are potential pathways for paracellular translocation of the pathogenic contents of the duodenum. It is not inconceivable that part of this intestinal pathogenic content can be translocated also by partially damaged cells. Evidence of the latter is the presence of microbial bodies in the cytoplasm of cells with partially destroyed plasmalemma (but preserved organelles and nucleus). An adaptive mechanism for ensuring the repair of damaged enterocytes is selective autophagy, which acts as a factor in the recycling of destroyed organelles and the cytoplasmic matrix, aimed primarily at maintaining cell viability.

Keywords: burn injury, streptozotocin-induced diabetes mellitus, intestinal epithelial barrier.

\section{Introduction}

Nowadays, due to the acceleration of urbanization and the growth of industrial use of heat energy, severe thermal burn injury resulting in burn disease is becoming one of the most important problems of practical medicine [26].

Diabetes has also been recognized as a global health and social challenge of the 21st century [21]. Diabetes mellitus and its related complications are becoming more common. The complex of gastrointestinal symptoms associated with diabetes is now known as diabetic enteropathy and can manifest as diarrhea, fecal 
incontinence, constipation, dyspepsia, nausea and vomiting [11]. The ancient theory that autonomic neuropathy is a major contributor to diabetic enteropathy $[17,18,25]$ has recently been supplemented by new theories of disease development [2]. In particular, it is now believed [11] that hyperglycemia and its associated oxidative stress in neural networks, including nitrergic neurons and interstitial cells of Cajal [2, 23], play a central role in the development of diabetic enteropathy. The authors of the latest (at the time of publication) scientific review article "Diabets and the small intestine" [11] indicate that the latest scientific results are promising, but there is still a great need for further studies of the pathogenesis of diabetic enteropathy.

As of today, the leading role of intestinal dysfunction in the development of complications of diabetes has been demonstrated $[2,11,17,18,25,28]$ and caused by severe burns of burn disease [9, 10, 21]. However, until now, the study of structural changes in the intestinal epithelial barrier of the duodenum in burn skin injury under its association with diabetes has not been the subject of special studies.

The aim of this work was to study the structural changes of the intestinal epithelial barrier in the duodenum in burn injury of skin in rat under experimental streptozotocin-induced diabetes mellitus.

\section{Materials and methods}

This study was conducted on laboratory white adult ratsmales weighing $180-210 \mathrm{~g}$. The control group consisted of 21 animals without somatic pathology, the first experimental group was 21 rats with burn skin injury, the second experimental group was 21 rats with skin burn and experimental streptozotocin-induced diabetes. All studies and control of the animals were conducted in accordance with the rules for the use of the animals in the experiments, adopted by the "European Convention for the Protection of Vertebrate Animals Used for Experimental and other Scientific Purposes" (Strasbourg, 1986), "General Ethica Principles of Animal Experiments", adopted by the First National Congress On Bioethics (Kyiv, 2001), "Ethical Principles and Guidelines for Experiments on Animals: 3rd Edition" (Switzerland 2005) and the Law of Ukraine "On the Protection of Animals from Cruel Treatment" (2006).

The model of experimental diabetes mellitus [20] was reproduced by administering streptozotocin to rats intraperitoneally at a dose of $50 \mathrm{mg} / \mathrm{kg}$, pre-dissolving it in $0.1 \mathrm{M}$ citrate buffer solution ( $\mathrm{pH}-4.5)$. The duration of the experiment was 1 month. The control of the development of hyperglycemia in the second experimental group was blood glucose level $-24.24 \pm 0.79 \mathrm{mmol} / \mathrm{L}$. In the control group $8.03 \pm 0.4 \mathrm{mmol} / \mathrm{L}$. In our study, burn injury of skin caused in accordance with the widespread model of researchers Regas F.C. and Ehrlich H.P. [24], which was slightly modified and optimized by Gunas I., Dovgan I. and Masur O. [12]. In the experimental simulation of skin burns, two copper plates in the form of an ellipse were kept in water at $100^{\circ} \mathrm{C}$ for 10 minutes and, under the conditions of ether anesthesia, were applied simultaneously symmetrically to both exposed rats with an exposure of 10 seconds. Burning skin damage in rats was II -A-B degree of dermal surface burn (according to the old classification III - A degree) with a total area of 21-23 $\%$ of the body surface with the development of burn shock. Many researchers $[4,5,7,13,14]$ have shown that under the conditions of using this model of experimental burn, the development of burn disease with such characteristic features as endogenous intoxication, generalized catabolic reaction, systemic inflammatory and apoptotic responses, polyorganic dysfunction is initiated. Duodenum was selected for morphological studies, fragments of which were processed by conventional methods of light and electron microscopy. Semi-thin and ultrathin sections from epoxy blocks were obtained on an LKB ultramicrotome (Sweden). Ultra-thin sections after appropriate contrast were examined under a PEM-125K electron microscope. Semi-thin sections were stained with methylene blue and toluidine blue. Sections of paraffin blocks were stained with hematoxylineosin. The main criteria for assessing damage to the duodenal mucosa enerocytes were the results of histological and ultrastructural data in dynamics 7, 14, and 21 days after skin burn. At that time, rats were given a single intraperitoneally high dose of sodium thiopental and were removed from the experiment by decapitation.

\section{Results}

In enterocytes of the mucous membrane of the duodenum of animals of the first experimental group 7 days after burns, the most characteristic feature of structural changes is the destruction of microvilli of the brush border of enterocytes, as well as changes of tight junctions. These contacts are clearly visualized on electron micrographs at the loci between the apicolateral surfaces of adjacent enterocytes with a brush border because the outer hydrophilic layers and the glycocalyx of adjacent plasmalemma seem to merge at one point into a public electron-dense layer with electron density (Fig. 1, 2). Note some chaotic arrangement of tight junctions

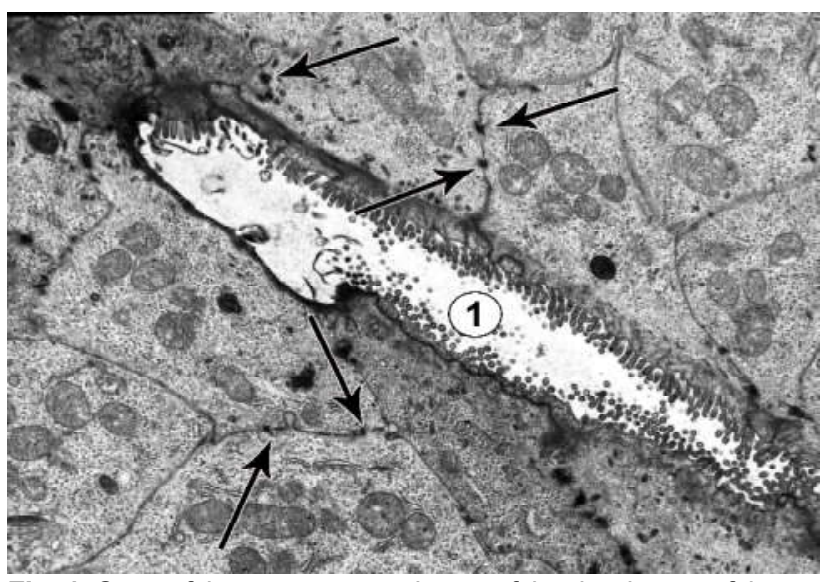

Fig. 1. Crypt of the mucous membrane of the duodenum of the rat of the first experimental group 7 days after burn. The arrows indicate dense contacts between the enterocytes with the brush border. 1 - crypt lumen. EM, x10000. 


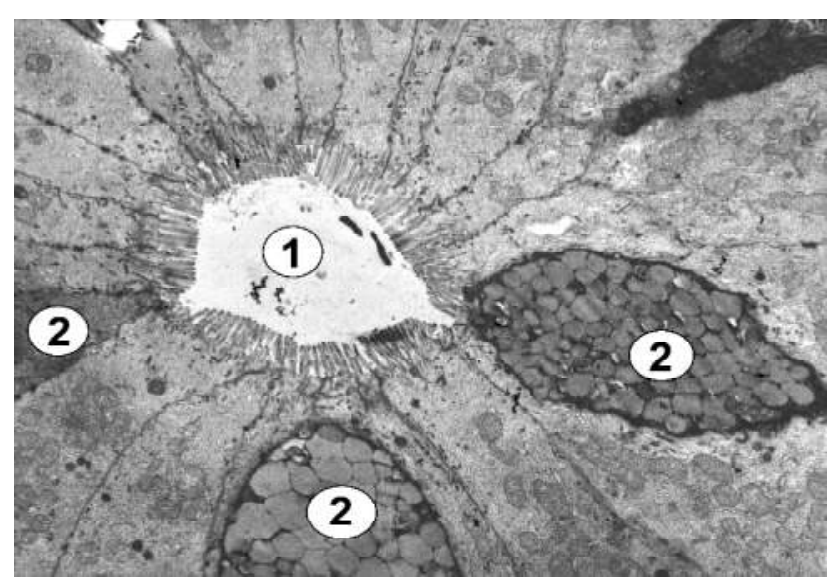

Fig. 2. Crypt of the duodenal mucosa of the rat under normal conditions (control group of animals). 1 - crypt lumen; 2 - cytoplasm of goblet cells. EM, $x 8000$.

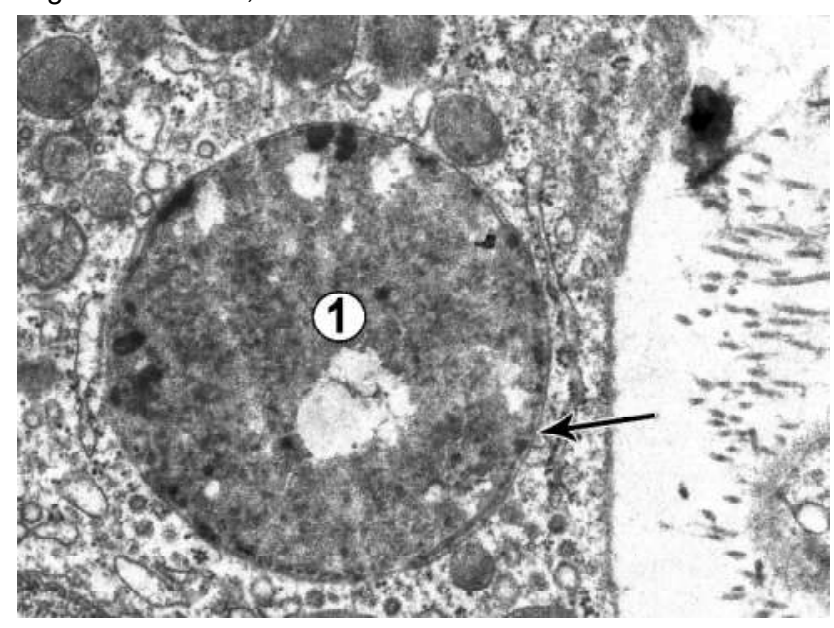

Fig. 3. Autophagolysosome (1) with heteromorphic electron-dense content in the cytoplasm of enterocyte with the remains of the brush border in the duodenal mucosa of the first experimental group 7 days after burn. The arrow marked the phagophore. EM, x25000.

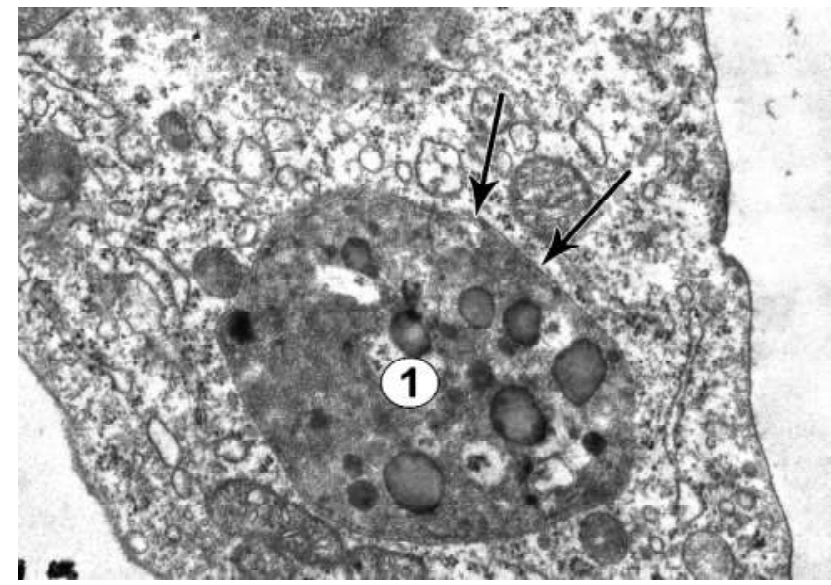

Fig. 4. Typical autophagolysosome (1) in the cytoplasm of the enterocyte with a brush border that has lost dense contact with adjacent enterocytes, in the mucous membrane of the duodenum of the rat of the first experimental group 21 days after burn. Arrows marked phagophore. EM, x25000. in the epithelial monolayer (intestinal epithelial barrier) of the duodenum in rats of the first experimental group (see Fig. 1), which deepens with increasing time after burn.

The intestinal barrier of the duodenum also includes goblet cells (see Fig. 2), which, under normal conditions, have a holistic plasmalemma (which, however, does not form dense contacts with adjacent enterocytes with a brush border), and numerous secretory vesicles, medium electron density material.

Widespread phenomenon in this time interval is a variety of ultrastructural changes of enterocytes against the background of swelling of their cytoplasm (an indicator of which is the enlightenment of the cytoplasmic matrix): from the vacuolation of tubules of the endoplasmic reticulum and damage to the mitochondria (manifestation is their intense swelling, fragmentation of the cristae and inner membrane) to the complete destruction of organelles, the appearance of defects of plasmalemma and karyolemma.

In sections of cytoplasm of enterocytes with partially lost brush border are located rounded autophagosomes and autophagolysosomes of different size with heteromorphic electron-dense contents (Fig. 3).

Morphological evidence of the initial stage of autophagy is the grouping of damaged cell organelles in certain loci of the cytoplasmic matrix and their sequestration by concentric coverage of the characteristic autophagosome structure phagophore (double insulating membrane). In the future, autophagosomes merge with lysosomes and form autophagosomes with different electron density and structure (which is an indicator of the stages and efficiency of digestion of the sequestered material).

Digestion of the content of autophagolysosomes is accompanied by destruction of the inner membrane of the phagophore (under these conditions, the products of digestion are likely to be absorbed and assimilated by the cytoplasm of the enterocyte). If part of the material remains undigested, then the autophagolysosome is transformed into an autophagic vacuole, which is directed to the plasmalemma of the apical region of the enterocyte and releases its contents outside.

In animals of the first experimental group, 14 days after burn in the duodenum, sections of the epithelial monolayer of enterocytes with preserved brush border alternated with areas free of brush border. The enterocytes of the epithelial monolayer were adjacent to desquamated cells of varying degrees of conservation. In the apical part of most enterocytes with partially lost brush border were located groups of rounded autophagosomes and autophagolysosomes of different size and content.

In the cytoplasm of many enterocytes with the presence of structural site defects of the plasmalemma and karyolemma in combination with local damage of the cytoplasmic matrix (which, given their variability, can probably be repaired) the signs of increase of functional activity of organelles are revealed (the evidence of which is a moderate expansion of the tubules of the granular endoplasmic 


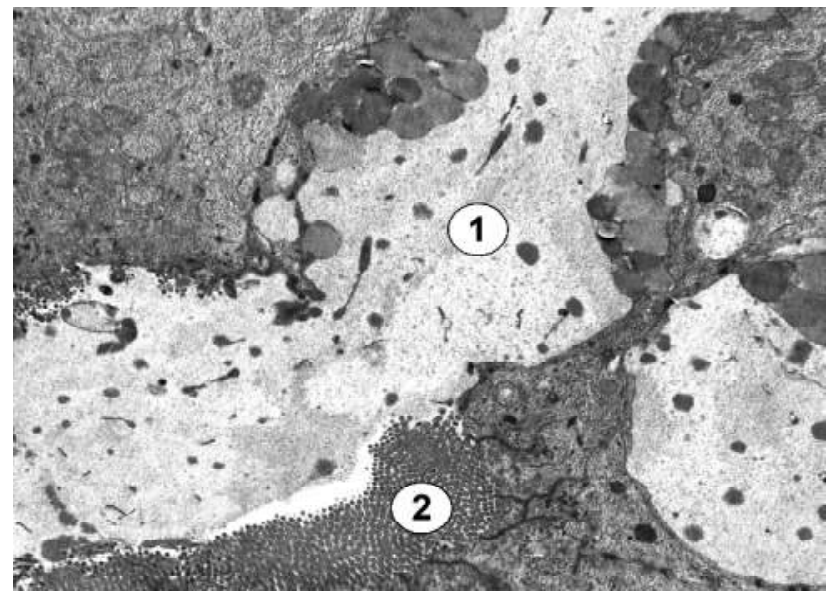

Fig. 5. Deformity of the lumen of the crypt of the mucous membrane of the duodenum of the rat of the second experimental group 7 days after burn. 1 - remnants of goblet cells in crypt lumen; 2 - the remnants of the brush border. EM, 25000.

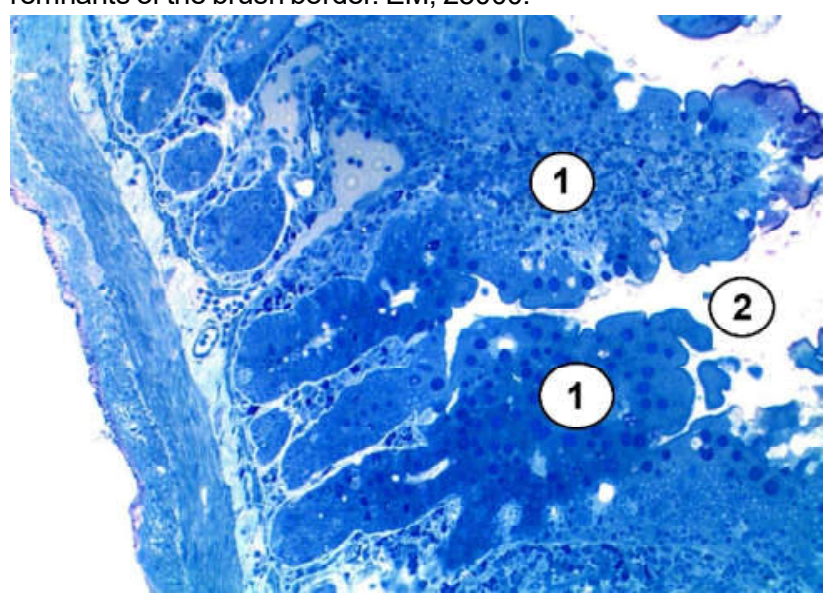

Fig. 6. Deformed villi and crypts of the mucous membrane of the duodenum of the rat of the second experimental group 21 days after burn. 1 - villi of the mucous membrane; 2 - intestinal lumen. Semi-thin section. Toluidine blue. $\times 100$.

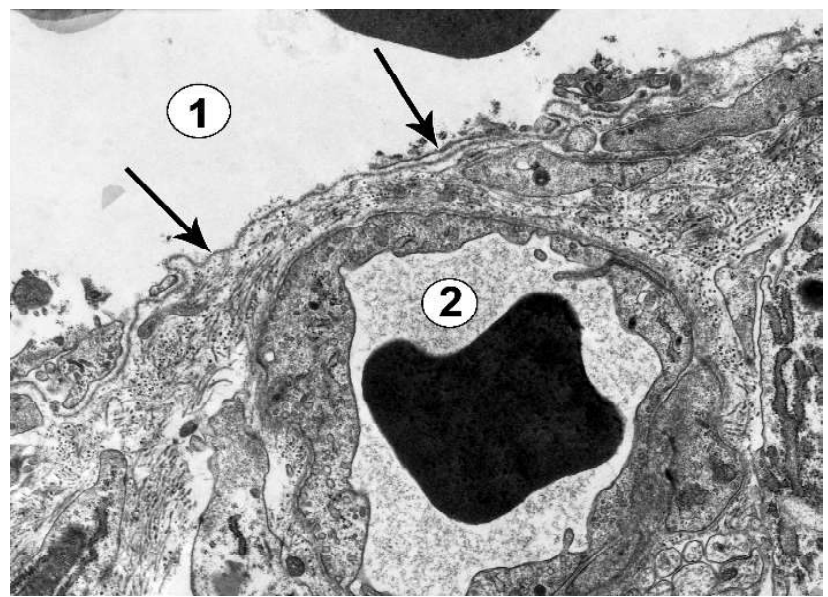

Fig. 7. Necrosis of the duodenal mucosa enterocyte of the duodenum of the rat of the second experimental group 21 days after burn. The arrows marked the "exposed" basement membrane of the epithelial monolayer. 1 - intestinal lumen; 2 - the lumen of the blood capillary. EM, x15000. reticulum, an increase in the number of ribosomes, the presence of polysome, the aggregation of intact mitochondria, the integrity of the nucleus). In other enterocytes, at this time, the cytoplasm is vacuolated in the form of various enlargement of the tubules of the endoplasmic reticulum with enlightenment of their contents, vacuolar transformation of mitochondria, which is completed by complete necrotic destruction and cell fragmentation with the formation of cellular detritus.

In animals of the first experimental group after 21 days, after burns, morphologically focal atrophy of the mucous membrane was manifested by thickening and shortening of the villi; in some places they were completely absent. The erosions that have resulted from necrosis of enterocytes with a brush border and destruction of goblet cells were quite often found. In many areas of the intestinal epithelial barrier (due to loss of tight contacts) adjacent brushbordered enterocytes were separated from each other, forming extended interepithelial spaces. Typical autophagolysosomes were detected in the cytoplasm of some of these enterocytes (Fig. 4).

The animals of the second experimental group after 7 days after the burn is common subtotal necrosis of enterocytes brush border, when the preservation of the cytoplasm of intact border area of necrotic cells subject to degeneration and cell detritus formed with microvilli border enters the intestinal area. Most goblet cells, which completely collapse after accumulation of secret, are destructive. If this occurs in crypts (Fig. 5), then the remains of goblet cells are included in the contents of the crypts and (along with enterocyte residues) deform their lumen.

14 days after burn in the mucous membrane of the duodenum of animals of the second experimental group, enterocytes in certain areas of the epithelial monolayer are subject to complete necrotic decay. In these areas, the basement membrane becomes "exposed". It is quite well preserved and even, it is somewhat thick compared to normal (in the control group of rats).

The structural changes described above are accompanied by deformation and destruction of the villi of the duodenal mucosa. The villi lose their typical leaf-like shape, often take on a "twisted" appearance, and filamentous villi appear, surrounded by groups of desquamated enterocytes and cellular detritus.

21 days after burns in animals of the second experimental group in some parts of the mucous membrane of the duodenum of the crypt and villi are clearly deformed. The villi lose their typical cytoarchitectonics and have the appearance of clustered (and sometimes mushroom) conglomerates of enterocytes of varying degrees of structural conservation (Fig. 6). To a greater extent, the intestinal epithelial barrier loses (Fig. 7) the integrity of the cellular component with partial preservation of the basement membrane (the first occurs both due to necrosis of the enterocytes with the brush border and due to complete destruction of the goblet cell). In all cases, defects exist in the intestinal epithelial barrier, 


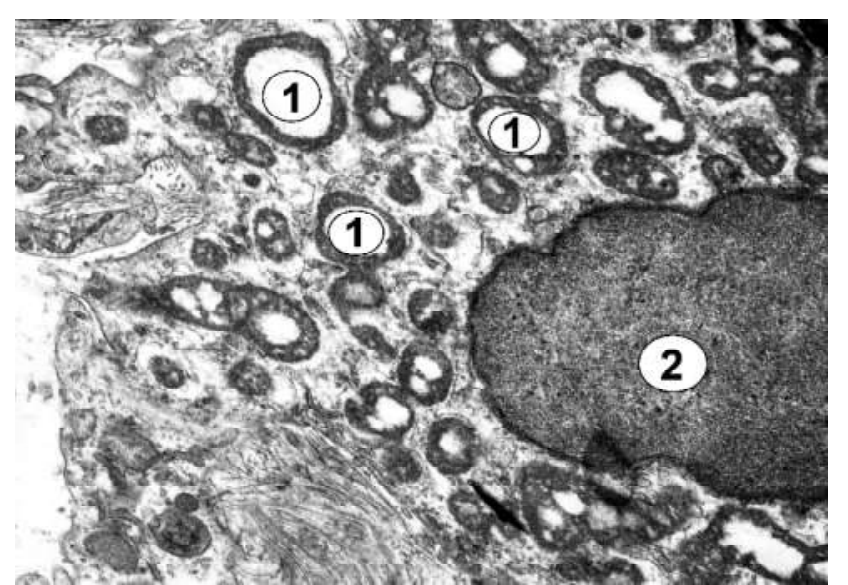

Fig. 8. Microbial bodies (1) in the cytoplasm of cells of the mucous membrane of the duodenum of the rat of the second experimental group 21 days after burn. 2 - the nucleus of the cell. EM, x20000.

which are potential pathways for paracellular translocation of the pathogenic contents of the duodenum. It is not inconceivable that part of this intestinal pathogenic content can be translocated and partially damaged by cells. Evidence of the latter is the presence of microbial bodies (Fig. 8) in the cytoplasm of cells with partially destroyed plasmalemma (but preserved organelles and nucleus).

\section{Discussion}

Many unresolved issues remain regarding the role of structural and functional changes in the small intestine in the pathogenesis of burn disease, and in particular, regarding dysfunction in the context of burns of the intestinal epithelial barrier [15].

The data obtained indicate the structural manifestations of a barrier violation (destruction of dense interepithelial contacts, disappearance of interdigitations of cytoplasmic processes of adjacent enterocytes) in burn skin injury under experimental streptozotocin-induced diabetes. In addition, we confirmed the Huang Ya. et al. data [16] regarding the involvement of autophagic processes in the development of gradual structural disorganization of the intestinal epithelial barrier, but unlike these authors, we consider their manifestation of an adaptive response.

It is worth noting that the role of autophagy in cell death is now widely regarded by researchers as quite controversial [16]. According to modern data [1], autophagy is the process of digestion of its own distorted organelles and sections of the cytoplasm by lysosomes (thus autophagy is both a type of programmed cell death and a strategy for cell survival by recycling cellular material). Thus, the adaptive response of the duodenal mucosa enterocytes to the destructive effects of burn disease factors involves the use as part of the plastic and energy resources of the degraded cellular material to repair the damaged enterocyte and to maintain its viability. Under the conditions of our experiment in rats of the first experimental group, the course of structural changes of enterocytes of the duodenal mucosa is slow enough to include the adaptive mechanism of autophagy of distorted organelles. In the animals of the second experimental group, destruction of cytoplasmic and organelle enterocyte sites (due to the summation of the factors of burn disease and diabetes) is accelerated and cells die by necrosis.

It should be noted separately that Nighot P.K., Hu C.A., and $\mathrm{Ma}$ T.Y. [22] suggest that autophagy promotes restrictive tight junction function and enhances the intestinal epithelial barrier by targeting claudin-2 protein degradation. In the context of this view, Elshaer D. and Begun G. [8] emphasize the crucial role of the barrier function of intestinal epithelium, autophagy and cytokines in providing intestinal homeostasis.

It is now widely accepted that intact intestinal epithelial barrier is critical for maintaining homeostasis in human health and disease, and tight enterocyte contacts are an integral part of this barrier [27]. It is known [6, 16] that permeability proteins occludin and zonulin-1 are involved in ensuring the functioning of tight junctions in the intestinal epithelial barrier. Severe burns of the skin have been found to increase the permeability of the intestinal epithelial barrier, which is accompanied by decreased expression and localization of occludin and zonulin-1 $[6,16]$.

We obtained data on structural changes of the intestinal epithelial barrier of the duodenum of rats in burn skin injury under experimental streptozotocin-induced diabetes mellitus, indicating an increase in the paracellular permeability of the barrier. In animals of the second experimental group, intestinal microbes were found to penetrate the defective intestinal epithelial barrier of the duodenum, which is consistent with the data [3] on the role of intestinal microbiota translocation in the pathogenesis of diabetes.

With the development of burn disease, the translocation of pathogenic microflora from the lumen of the intestine to other organs leads to deepening of the systemic inflammatory response syndrome, hypermetabolism, multiple organ failure, sepsis. Such translocation is a factor in the worsening of diabetes mellitus [3, 19], which was once witnessed by Vaarala O. et al. [28], calling the intricate relationship between gut microbiota, permeability of the intestinal epithelial barrier and mucosal immunity a "perfect storm" for diabetes.

Summarizing, in the duodenal mucosa of rats of the second experimental group, the dynamics of morphological changes during different periods after burns (7 days - the stage of shock and early toxemia; 14 days - the stage of late toxemia; 21 days - the stage of septicotoxemia) differ from animals of the first experimental group. Comparison of the data obtained with those previously revealed suggests that the time intervals and the nature of the adaptive duodenal intestinal epithelial barrier are largely prolonged and impaired. Significant lesions of the intestinal epithelial barrier should lead to disruption of the processes of the digestive system, parietal digestion and absorption, as well as immunological protection (considering that the intestinal 
epithelial barrier is the first zone of contact of the organism with environmental antigens and and the leading element of the immune system), which undoubtedly affects the condition of the body with burns and, to a large extent, determines the development of burn disease, as well as the course of diabetes. The prospect of further research in this direction is related to the study of the effects on the duodenum of drugs that reduce the intoxication of the body and blood sugar level.

\section{Conclusions}

1. In the basis of damage to the enterocytes of the duodenal mucosa of rats with burn skin injury there are deep destructive changes, which after 21 days (in the stage of septicotoxemia), as a rule, are not reverse and develop

\section{References}

[1] Anding, A. L., \& Baehrecke, E. H. (2015). Autophagy in cell life and cell death. Current topics in developmental biology, 114, 67-91. doi: 10.1016/bs.ctdb.2015.07.012

[2] Azpiroz, F., \& Malagelada, C. (2016). Diabetic neuropathy in the gut: pathogenesis and diagnosis. Diabetologia, 59(3), 404408. https://doi.org/10.1007/s00125-015-3831-1

[3] Blandino, G., Inturri, R., Lazzara, F., Di Rosa, M., \& Malaguarnera, L. (2016). Impact of gut microbiota on diabetes mellitus. Diabetes \& metabolism, 42(5), 303-315. doi: 10.1016/ j.diabet.2016.04.004

[4] Cherkasov, V. G., Kovalchuk, A. I., Dzevulskaya, I. V., Malikov, A. V., Lakhtadyr, T. V., \& Matkivskaya, R. M. (2015). Structural transformations in the internal organs with infusion therapy for burn disease. Medical science of Ukraine, 11(3-4), 4-11.

[5] Cherkasov, V. G., Kovalchuk, A. I., Dzevulskaya, I. V., \& Cherkasov, E. V. (2015). Evaluation of the effect of infusion of composite hyperosmolar solutions on the structure of neuroimmunoendocrine system organs in burn diseas. European International Journal of Science and Technology, 4(9), 51-61.

[6] Costantini, T. W., Loomis, W. H., Putnam, J. G., Drusinsky, D., Deree, J., Choi, S., ... \& Coimbra, R. (2009). Burn-induced gut barrier injury is attenuated by phosphodiesterase inhibition: effects on tight junction structural proteins. Shock (Augusta, Ga.), 31(4), 416-422. doi: 10.1097/SHK. obo13e3181863080

[7] Dzevulska, I. V., Kovalchuk, O. I., Cherkasov, E. V., Majewskyi, O. Y., Shevchuk, Y. G., Pastukhova, V. A., \& Kyselova, T. M. (2018). Influence of lactoproteinum solution with sorbitol on dna content of cells of endocrine glands on the background of skin burn in rats. World of medicine and biology, 14(64), 033-039. doi: 10.26724/2079-8334-2018-2-64-33-39

[8] Elshaer, D., \& Begun, J. (2017). The role of barrier function, autophagy, and cytokines in maintaining intestinal homeostasis. In Seminars in cell \& developmental biology (Vol. 61, pp. 5159). Academic Press. doi: 10.1016/j.semcdb.2016.08.018

[9] Evers, L. H., Bhavsar, D., \& Mailänder, P. (2010). The biology of burn injury. Experimental dermatology, 19(9), 777-783. doi: 10. 1111/j.1600-0625.2010.01105.x

[10] Galunko, G. M. (2017). Histological changes in the small intestine in the advanced stages of burn diseases. World of Medicine and Biology, 3(61), 90-96. doi: 10.26724/ 2079-8334-2017-361-90-96

[11] Gotfried, J., Priest, S., \& Schey, R. (2017). Diabetes and the small intestine. Curr Treat Options Gastroenterol, 15(4), 490- on the background of significant intoxication.

2. The revealed structural changes of the enterocytes are evidence of a violation of the structural integrity of the intestinal epithelial barrier. In animals of the first and second (mostly) experimental groups, the damaged epithelium of the duodenal mucosa critically weakens the adequacy of its function of the interface between the mucous membrane and the environment of the intestinal lumen, and is not capable of structurally providing a reliable barrier against toxins, pathogens and antigenic molecules.

3. The adaptive mechanism for ensuring the repair of damaged enterocytes is selective autophagy, which acts as a factor in the recycling of destroyed organelles and the cytoplasmic matrix, aimed primarily at maintaining cell viability.

507. doi: 10.1007/s11938-017-0155-x

[12] Gunas, I., Dovgan, I., \& Masur, O. (1997). Method of intermal burn trauma correction by means of cryoinfluence. Abstracts are presented in zusammen mit der Polish Anatomical Society with the participation of the Association des Anatomistes Verhandlungen der Anatomishen Geselleschaft, Olsztyn ( $p$. 105). Jena-Munchen: Der Urban \& Fisher Verlag.

[13] Gunas, I. V., Guminskiy, Y. I., Ocheretn, N. P., Lysenko, D. A., Kovalchuk, O. I., Dzevulska, I. V., \& Cherkasov, E. V. (2018). Indicators cell cycle and dna fragmentation of spleen cells in early terms after thermal burns of skin at the background of introduction $0.9 \% \mathrm{NaCl}$ solution. World of Medicine and Biology, 14(63), 116-120. doi: 10.26.724/2079-8334-2018-1-63-116120

[14] Gunas, I. V., Kovalchuk, O. I., Cherkasov, V. G., \& Dzevulskaya, I. V. (2014). Structural aspects of the organs adaptive changes of the neuroimundocrine system in the treatment of burn disease with combined hyperosmolar solutions. Galician Medical Herald, 21(2), 21-26.

[15] Hietbrink, F., Besselink, M. G., Renooij, W., de Smet, M. B., Draisma, A., van der Hoeven, H., \& Pickkers, P. (2009). Systemic inflammation increases intestinal permeability during experimental human endotoxemia. Shock, 32(4), 374-378. doi: 10.1097/SHK.obo13e318a2bcd6

[16] Huang, Y., Feng, Y., Wang, Y., Wang, P., Wang, F., \& Ren, H. (2018). Severe burn-induced intestinal epithelial barrier dysfunction is associated with endoplasmic reticulum stress and autophagy in mice. Frontiers in physiology, 9, 441. doi: 10.3389/fphys.2018.00441

[17] Ihana-Sugiyama, N., Nagata, N., Yamamoto-Honda, R., Izawa, E., Kajio, H., Shimbo, T., ... \& Noda, M. (2016). Constipation, hard stools, fecal urgency, and incomplete evacuation, but not diarrhea is associated with diabetes and its related factors. World journal of gastroenterology, 22(11), 3252-3260. doi: 10.3748/wjg.v22.i11.3252

[18] Khoshbaten, M., Madad, L., Baladast, M., Mohammadi, M., \& Aliasgarzadeh, A. (2011). Gastrointestinal signs and symptoms among persons with diabetes mellitus. Gastroenterology and hepatology from bed to bench, 4(4), 219-223. PMID: 24834186

[19] Knip, M., \& Siljander, H. (2016). The role of the intestinal microbiota in type 1 diabetes mellitus. Nature Reviews Endocrinology, 12(3), 154-167. doi: 10.1038/nrendo.2015.218.

[20] Natrus, L. V., Ryzhko, I. N., Kozak, A. I., Kryvosheieva, O. I., \& Stechenko, L. A. (2017). Ultrastructural base of the connective 
tissue skin'cells interactions at burn injury in the hyperglycemic white rats. World of Medicine and Biology, 13(62), 157-162. doi: 10.26724/2079-83342017-4-62-157-162

[21] Netyukhailo, L. G., Kharchnko, S. V., \& Kostenko, A. G. (2011). Pathogenesis of burn disease (in 2 parts). World of Medicine and Biology, (1), 127-135.

[22] Nighot, P. K., Hu, C. A., \& Ma, T. Y. (2015). Autophagy enhancement of intestinal epithelial tight junction barrier function by targeting claudin-2 degradation. J. Biol. Chem., 290, 7234-7246. doi: 10.1074/jbc.M114.597492

[23] Pasternak, A., Szura, M., Gil,. K., \& Matyja, A. (2016). Interstitial cells of Cajal - systematic review. Folia Morphol., 75(3), 281286. doi: 10.5603/FM.a2016.0002

[24] Regas, F. C., \& Ehrlich, H. P. (1992). Elucidating the vascular response to burns with a new rat model. J. Trauma, 32(5),
557-563. doi: 10.1097/00005373-199205000-00004

[25] Rodrigues, M. L., \& Motta, M. E. (2012). Mechanisms and factors associated with gastrointestinal symptoms in patients with diabetes mellitus. J. Pediatr., 88(1), 17-24. doi: 10.2223/ JPED.2153

[26] Smolle, Ch., Cambiaso-Daniel, J., \& Forbes, A. A. (2017). Recent trends in burn epidemiology woredwide: A systemic review. Burns, 43(2), 249-257. doi: 10.1016/j.burns.2016.08.013

[27] Turner, J. R. (2009). Intestinal mucosal barrier function in health and disease. Nat Rev. Immunol., 9(11), 799-809. doi: 10.1038/ nri2653

[28] Vaarala, O., Atkinson, M. A, \& Neu, J. (2008). The "Perfect Storm" for Type 1 Diabetes: the complex interplay between intestinal microbiota, gut permeability, and mucosal immunity. Diabetes, 57(10), 2555-2562. https://doi.org/10.2337/db08-0331

\section{СТРУКТУРНІ ЗМІНИ ІНТЕСТІНАЛЬНОГО ЕПІТЕЛІАЛЬНОГО БАР'ЄРА ДВАНАДЦЯТИПАЛОЇ КИШКИ ЩУРІВ ПРИ ОПІКОВІЙ ТРАВМІ ШКІРИ ЗА УМОВ ЕКСПЕРИМЕНТАЛЬНОГО СТРЕПТОЗОТОЦИНІНДУКОВАНОГО ЦУКРОВОГО ДІАБЕТУ \\ Тимошенко I.O.}

Метою роботи було вивчення структурних змін інтестінального епітеліального бар'єра дванадиятипалої кишки при опіковій травмі шкіри щура за умов експериментального стрептозотоциніндукованого иукрового діабету. Дослідження здійснене на лабораторних білих статевозрілих щурах-самцях масою 180-210 2. Групу контролю склали 21 тварина без соматичної патології, першу експериментальну групу склали - 21 щур з опіковою травмою шкіри, другу експериментальну групу склали - 21 щур з опіком шкіри та експериментальним стрептозотоциніндукованим діабетом. Модель експериментального цукрового діабету відтворювали шляхом введення щурам стрептозотоцину внутрішньоочеревинно одноразово в дозі 50 мг/ке. Термічне опікове пошкодження шкіри у щурів відповідало II - А-Б ступеню дермального поверхневого опіку (за старою класифікацією III - А ступінь) загальною площею 21-23 \% поверхні тіла з розвитком опікового шоку. Для морфологічних досліджень вилучали відділ дванадцятипалої кишки, фррагменти якого обробляли загальноприйнятими методами світлової та електронної мікроскопії. Основними критеріями оцінки пошкодження ентероцитів слизової оболонки дванадцятипалої кишки стали результати дослідження щодо порівняння гістологічних та ультраструктурних даних в динаміці через 7, 14, та 21 добу після опіку шкіри. Результати проведених досліджень показали, що в основі пошкоджень інтестінального епітеліального бар'єра дванадиятипалої кишки лежать глибокі деструктивні зміни, які через 21 добу (в стадії септикотоксемії), як правило, мають незворотній характер і розвиваються на фоні значної інтоксикації організму. Відмічено зменшення кількості шільних контактів в інтестінальному епітеліальному бар'єрі дванадиятипалої кишки щурів першої та другої експериментальних груп та втрата упорядкованості (набуття певної хаотичності) їхньої локалізації у міру збільшення часу після опікової травми. На більшій своїй протяжності інтестінальний епітеліальний бар'єр втрачає цілісність клітинної складової при частковій збереженості базальної мембрани (перше відбувається як за рахунок некрозу ентероцитів з щіточковою облямівкою, так і за рахунок повної деструкції келихоподібних клітин). У всіх випадках в інтестінальному епітеліальному бар'єрі з'являються дефекти, які є потенційними шляхами парацелюлярної транслокації патогенного вмісту дванадиятипалої кишки. Не виключно, що частина цього інтестінального патогенного вмісту може бути транслокована і через частково пошкоджені клітин. Свідченням останнього є виявлена наявність мікробних тіл в цитоплазмі клітин з частково зруйнованою плазмолемою (але збереженими органелами та ядром). Адаптивним механізмом щодо забезпечення репарації ушкоджених ентероцитів є селективна автофагія, яка виступає чинником рециклізації матеріалу зруйнованих органел $і$ цитоплазматичного матриксу, спрямованого, в периу чергу, на підтримку життєздатності клітин.

Ключові слова: опікова травма, стрептозотоциніндукований цукровий діабет, інтестінальний епітеліальний бар'єр.

\section{СТРУКТУРНЫЕ ИЗМЕНЕНИЯ ИНТЕСТИНАЛЬНОГО ЭПИТЕЛИАЛЬНОГО БАРЬЕРАДВЕНАДЦАТИПЕРСТНОЙ КИШКИ КРЫС ПРИ ОЖОГОВОЙ ТРАВМЕ КОЖИ В УСЛОВИЯХ ЭКСПЕРИМЕНТАЛЬНОГО СТРЕПТОЗОТОЦИНИНДУЦИРОВАННОГО САХАРНОГО ДИАБЕТА \\ Тимошенко И.А.}

Целью работы было изучение структурных изменений интестинального эпителиального барьера двенадцатиперстной кишки при ожоговой травме кожи крысы в условиях экспериментального стрептозотоцининдуцированного сахарного диабета. Исследование осуществлено на лабораторных белых половозрелых крысах-самцах массой 180-210 г. Группу контроля составили 21 животное без соматической патологии, первую экспериментальную группу составили - 21 крыса с ожоговой травмой кожи, вторую экспериментальную группу составили - 21 крыса с ожогом кожи и экспериментальным стрептозотоцининдуцированным диабетом. Модель экспериментального сахарного диабета воспроизводили путем введения крысам стрептозотоцина внутрибрюшинно однократно в дозе 50 мг/кг. Термическое ожоговое повреждение кожи у крыс соответствовало II - А-Б степени дермального поверхностного ожога (по старой классифрикации III - A степень) общей площадью 21-23 \% поверхности тела с развитием ожогового шока. Для морфологических исследований изымали отдел двенадиатиперстной кишки, фррагменты которого обрабатывали общепринятыми методами световой и электронной микроскопии. Основными критериями оценки повреждения энтероцитов слизистой оболочки двенадцатиперстной кишки стали результаты сравнения гистологических и ультраструктурных данных в динамике через 7, 14 и 21 сутки после ожога кожи. Результаты проведенных исследований показали, что в основе повреждений интестинального эпителиального барьера двенадиатиперстной кишки лежат глубокие деструктивные изменения, которые через 21 день (в стадии 
септикотоксемии), как правило, имеют необратимый характер и развиваются на фоне значительной интоксикации организма. Отмечено уменьшение количества плотных контактов в интестинальном эпителиальном барьере двенадцатиперстной кишки крыс первой и второй экспериментальных групп и потеря упорядоченности (приобретение определенной хаотичности) их локализации по мере увеличения времени после ожоговой травмы. На большей части своей протяженности интестинальный эпителиальный барьер теряет целостность клеточной составляющей при частичной сохранности базальной мембраны (первое происходит как за счет некроза энтероцитов с щеточной каймой, так и за счет полной деструкции бокаловидных клеток). Во всех случаях в интестинальном эпителиальном барьере появляются дефекты, которые являются потенциальными путями парацеллюлярной транслокации патогенного содержимого двенадцатиперстной кишки. Часть этого интестинального патогенного содержания может быть транслоцирована и через частично поврежденные клетки. Свидетельством последнего является выявленное наличие микробных тел в цитоплазме клеток с частично разрушенной плазмолеммой (но сохранившимися органеллами и ядром). Адаптивным механизмом по обеспечению репарации поврежденных энтероцитов является селективная аутофагия, которая выступает фактором рециклизации материала разрушенных органелл и цитоплазматического матрикса, направленного, в первую очередь, на поддержание жизнеспособности клеток.

Ключевые слова: ожоговая травма, стрептозотоцининдуцированный сахарный диабет, интестинальный эпителиальный барьер. 